\title{
Manpower forecasting in the western world: The current state of the art
}

Citation for published version (APA):

van Eijs, P. W. L. J. (1994). Manpower forecasting in the western world: The current state of the art. Researchcentrum voor Onderwijs en Arbeidsmarkt, Faculteit der Economische Wetenschappen. ROA Research Memoranda No. 1E https://doi.org/10.26481/umaror.199401E

Document status and date:

Published: 01/01/1994

DOI:

10.26481/umaror.199401E

Document Version:

Publisher's PDF, also known as Version of record

\section{Please check the document version of this publication:}

- A submitted manuscript is the version of the article upon submission and before peer-review. There can be important differences between the submitted version and the official published version of record.

People interested in the research are advised to contact the author for the final version of the publication, or visit the DOI to the publisher's website.

- The final author version and the galley proof are versions of the publication after peer review.

- The final published version features the final layout of the paper including the volume, issue and page numbers.

Link to publication

\footnotetext{
General rights rights.

- You may freely distribute the URL identifying the publication in the public portal. please follow below link for the End User Agreement:

www.umlib.nl/taverne-license

Take down policy

If you believe that this document breaches copyright please contact us at:

repository@maastrichtuniversity.nl

providing details and we will investigate your claim.
}

Copyright and moral rights for the publications made accessible in the public portal are retained by the authors and/or other copyright owners and it is a condition of accessing publications that users recognise and abide by the legal requirements associated with these

- Users may download and print one copy of any publication from the public portal for the purpose of private study or research.

- You may not further distribute the material or use it for any profit-making activity or commercial gain

If the publication is distributed under the terms of Article $25 \mathrm{fa}$ of the Dutch Copyright Act, indicated by the "Taverne" license above, 
MANPOWER FORECASTING IN THE WESTERN

WORLD: THE CURRENT STATE OF THE ART

ROA-RM-1994/1E

Patrick van Eijs

RESEARCH CENTRE FOR EDUCATION AND THE LABOUR MARKET

Faculty of Economics and Business Administration

Rijksuniversiteit Limburg

Maastricht, January 1994 


\section{CIP-GEGEVENS KONINKLIJKE BIBLIOTHEEK, DEN HAAG}

Eijs, Patrick van

Manpower forecasting in the western world: the current state of the art / Patrick van Eijs. Maastricht: Research Centre for Education and the Labour Market, Faculty of Economics and Business Administration, Rijksuniversiteit Limburg. - (ROA-RM-1994/1E)

Met lit. opg.

ISBN 90-5321-120-9

Trefw.: arbeidsmarkt; toekomstverwachtingen. 


\section{CONTENTS}

Page

ABSTRACT

i

$\begin{array}{lll}1 . & \text { INTRODUCTION } & 1\end{array}$

2. THE CURRENT ROLE OF MANPOWER FORECASTING 4

2.1. Introduction 4

2.2. The two functions of manpower forecasting 4

$\begin{array}{ll}\text { 2.3. Evaluation } & 6\end{array}$

3. THE OUTPUT 10

$\begin{array}{ll}3.1 . & 10\end{array}$

$\begin{array}{ll}\text { 3.2. The current practice } & 10\end{array}$

$\begin{array}{ll}\text { 3.3. Evaluation } & 12\end{array}$

4. THE METHODOLOGY 17

$\begin{array}{ll}\text { 4.1. Introduction } & 17\end{array}$

$\begin{array}{ll}\text { 4.2. The supply side } & 17\end{array}$

$\begin{array}{ll}\text { 4.3. The demand side } & 18\end{array}$

4.4. Evaluation 20

5. CONCLUSIONS: A VIEW ON THE FUTURE OF MANPOWER FORECASTING $\quad 22$

5.1. The current state of the art 22

5.2. A view on the future of manpower forecasting 22

$\begin{array}{lr}\text { REFERENCES } & 25\end{array}$ 



\begin{abstract}
Manpower forecasting deals with projecting the occupational and educational structure of labour demand and supply. This paper goes into the current practice in manpower forecasting. The emphasis is on evaluating. Three aspects are distinguished: the function of manpower forecasting, the output and the methodology. More concrete, among others, the following aspects are discussed: the policy and the information function of manpower forecasting, the time horizon of manpower forecasts, the usefulness of educational forecasts, the usefulness of confrontations between demand and supply and the drawbacks of trend extrapolation. Based on the evaluation of the current state of the art, a view on the future of manpower forecasting is given.
\end{abstract}

The conclusions can be summarized as follows. The most promising role of manpower forecasting is providing information for, in particular, students to make the labour market more transparent. This implies that it seems recommendable to switch from demand-oriented to student-oriented forecasting. Furthermore, more attention should be paid to an economic foundation of manpower forecasts. In particular, the modelling of the interaction between demand and supply seems to be the most promising field of research.

I would like to thank Lex Borghans, Andries de Grip and Hans Heijke of ROA, Ronald Kutscher of BLS and Rob Wilson of IER for their helpful comments. 



\section{INTRODUCTION}

The labour market has some characteristic features. Firstly, it is a heterogeneous market. It consists of a lot of market segments, between which interactions are restricted. For example: both demand for and supply of carpenters on the one hand and economists on the other hand are completely separated. Secondly, there are some serious inflexibilities, for example: wage rigidities, immobility of both supply and demand and rigidities laid down by law or collective bargaining. Furthermore, inflexibilities are caused by the fact that adjustments in the labour market often take a long time; usually long-term investments are needed to adapt the structure of demand (for example: to fit in a new production technology) and supply (for example: to pursue a particular course). Finally, the labour market is not transparent; there is a serious lack of information on both the demand and the supply side of the market.

The consequences of these characteristics of the labour market can be very serious. Demand and supply rarely are in alignment with each other. As a result, mismatch phenomena can occur, that is, the agents' labour market position can fall short of expectations. Unemployment is the most obvious mismatch phenomenon. Other phenomena are, for example: unfulfilled vacancies, under- or overutilization of skills (as a result of downward displacement or upward substitution), student's career expectations that do not come true, cobweb cycles and the need to work overtime. These mismatches may cause serious economic and social problems: a decrease in economic growth, persisting unemployment, dissatisfaction of employees, firms moving abroad, etc..

It is not surprising that much attention has been paid to instruments that can contribute to the avoidance of these mismatches and consequent labour market problems. One of these instruments is manpower forecasting. Manpower forecasting deals with projecting the labour demand and supply, especially the occupational and educational structure of demand and supply ${ }^{1}$. These forecasts may be useful for all labour market participants. For example: students may use them as a guideline for making their educational choices, employers may use them as a guideline for their long-term personnel management or investment decisions, public sector administrators may use the forecasts as a starting point for making labour market and educational policies, etc.. To put it briefly, manpower forecasting may in general have two functions: (1) a policy function: that is, being a tool for (governmental) policy makers and (2) an information function: that is, informing labour market agents, like students and employers, in order to make the labour market more transparent.

Making manpower forecasts usually consists of several stages:

1. forecasting employment by industry with the help of a multi-industry model;

2. using this forecast to forecast the occupational structure of labour demand by industry;

3. translating the occupational forecasts into forecasts of labour demand by type of education;

1. Strictly speaking, a distinction can be made between forecasts and projections (see Blaug, 1967). However, in this paper this distinction is not made and only the term 'forecasts' is used. 
4. forecasting the educational structure of labour supply;

5 . confronting the demand and supply forecasts ${ }^{2}$.

It will be shown in this paper, however, that in practice often one or more stages are passed over.

In a preceding paper (Van Eijs, 1993) a historical overview of macroeconomic manpower forecasting is given. This paper aims to go into and evaluate the current 'state of the art' in manpower forecasting in the Western world. That is, it proposes to answer the following questions:

1. What is the current role of manpower forecasting?

2. What kind of manpower forecasts are made and how are they presented?

3. Which methodologies are used to make manpower forecasts?

The first question deals with the distinction between the policy function and the information function mentioned above. The second question deals with issues like the use of quantitative or qualitative forecasts, the use of scenarios and the way in which demand and supply are confronted. The third question deals with the models used to make occupational and educational forecasts. Attention is paid to both the demand and the supply side.

This paper tries to go further than answering these questions. The emphasis is on evaluating the current manpower forecasting practice. Attempts are made to evaluate the 'current state of the art' in an economically founded way. These evaluations are used to give a view on the future of manpower forecasting ${ }^{3}$.

The scope of this paper is restricted in two ways. Firstly, the emphasis is on research done by some important manpower forecasting institutes: the 'Bureau of Labor Statistics' (BLS, United States), the 'Institute of Employment Research' (IAB ${ }^{4}$, Germany), the 'Institute for Employment Research' (IER, United Kingdom) and the 'Research Centre for Education and the Labour Market' (ROA ${ }^{5}$, the Netherlands). In the Western world, these four institutes set the tone. This implies that a representative picture can be given by describing the work of these four institutes. Secondly, a restriction is made with regard to the third question. The paper concentrates on manpower forecasting, that is on forecasting the occupational and educational structure of the labour demand and supply by industry. Therefore, stage (1) mentioned above is left out, because this stage is in fact an input for making manpower forecasts. Furthermore, this stage is often based on work done by others. Manpower forecasting institutes cooperate with institutes specialized in macroeconomic modelling.

2. In these stages, some major elements of the famous 'manpower requirements approach' can be found (see, for example, Psacharopoulos, 1987).

3. This paper may be considered to be a supplement to Hughes (1993). Hughes describes the current state, in this paper the emphasis is on sketching the background and evaluating the current state.

4. Abbreviation of 'Institut für Arbeitsmarkt und Berufsforschung'.

5. Abbreviation of 'Researchcentrum voor Onderwijs en Arbeidsmarkt'. 
$-3-$

The structure of the remainder of this paper is as follows. Section 2 pays attention to the first question concerning the role of manpower forecasting. It describes the function of manpower forecasting in the four countries mentioned above. Furthermore, an evaluation of this current role is made. Section 3 discusses and evaluates the output and the way in which the forecasts are presented. Section 4 deals with the last question, concerning the methodology. It discusses the ways in which the occupational and educational forecasts are made and the background of the use of the methodologies. This section is also finished by an evaluation. Finally, in section 5 a rounding off is made. Some concluding remarks with regard to the current state of the art are made and a view on the future of manpower forecasting is given. 
$-4-$

\section{THE CURRENT ROLE OF MANPOWER FORECASTING}

\subsection{Introduction}

During the 1960s, economies changed rapidly and the educational system was more and more considered to be an important link in the economic process. Therefore, educational planning got an important role in governmental policy making. Initiated by the OECD, manpower forecasting in general and the manpower requirements approach in particular were considered to be important tools in educational planning, because they were in alignment with both the planning concept and the view on the labour market in those days (see, for example Parnes, 1962). However, at the end of the 1960s, the great popularity of manpower forecasting called forth a lot of criticism. Consequently, the popularity declined rapidly. However, manpower forecasters have replied to the remarks made by the critics (see Van Eijs, 1993). As a result, manpower forecasting did not drop out of the picture. It is still down for political and academic consideration.

Although manpower forecasting has survived the serious criticism during the last twenty-five years, its role has changed substantially, especially in the Western world. The planning function has disappeared almost completely. As mentioned in section 1, manpower forecasting is considered to have two functions: (1) a policy function: that is, being a tool for (governmental) policy makers and (2) an information function: that is, making the labour market more transparent by informing labour markets agents like students and employers.

In this section, the current role of manpower forecasting is discussed. Firstly, attention is paid to the way in which manpower forecasting fills the two functions mentioned above. Secondly an evaluation of the current role of manpower forecasting is made.

\subsection{The two functions of manpower forecasting}

An important function of manpower forecasting is informing the policy makers about future trends in the occupational and educational structure of labour demand and supply and drawing conclusions from the calculations in the form of policy recommendations or evaluations of policy proposals. This is the policy function of manpower forecasting, which can be found in the following statement of Wilson (1993, p. 4). This statement reflects IER's view on the role of manpower forecasting:

"Our prime objective, therefore, is to provide a set of 'points of reference' for policy makers and other interested parties. These should indicate the sort of economic environment they are likely to face, highlighting the main problem areas, quantifying the scale of any difficulties that may be foreseen, and estimating the impact of different policies.' 
This statement shows that: (1) policy makers come first and (2) evaluating different policies plays an important role. So IER's view on manpower forecasting implies that the policy function is the most important one. The policy function is preferred to the information function, because IER has some misgivings about the accuracy of manpower forecasts. IAB subscribes IER's view. Tessaring (1993, p. 107) states that, although it would be misleading to pretend that the future trends can be predicted exactly:

"...the public has a right to planning with a view to the future and thus a great interest in statements regarding possible future trends - whether pointing out undesirable developments (warning function of projections), ways to achieve a desired result (normative function), or at least a range of possible future scenarios (alternative/flexible forecasts)."

Furthermore, this statement shows that the policy function can be considered as a less imperative remainder of the planning function of the 1960s. Especially the normative function mentioned by Tessaring indicates this.

Manpower forecasting institutes often become specific assignments in which the policy function can be found. Some (Dutch) examples are the so-called 'Zeehavenstudie' (Seaportstudy, Voorlopige Nationale Havenraad, 1982) in which policy recommendations, based on manpower forecasts, are made to close the gaps between labour demand and supply in some Dutch seaport areas, Studies of the Central Planning Bureau (CPB) which are used by the Dutch government ${ }^{6}$, the ANTOS-study (Nederlands Economisch Instituut, 1983) which is carried out by commission of the Dutch Ministry of Social Affairs and Employment and, finally, Nederlands Economisch Instituut (1986) in which especially the policy implications of gaps between labour demand and supply are stressed (see the introductory section).

IER and IAB emphasize the policy function of manpower forecasting. BLS and ROA, on the other hand, stress the importance of manpower forecasts as a tool to improve the performance of the labour market; in other words: their forecasts primarily have an informational function. Rosenthal $(1992$, p. 32) states the view of BLS as follows:

"The Bureau of Labor Statistics occupational projections are a valuable resource for counsellors, students, and others concerned with the future occupational composition of the U.S. labor force."

This statement shows that: (1) counsellors and students come first and (2) the manpower forecasts are considered as a resource of information.

6. See for example Centraal Planbureau (1987), in which the director of the CPB (De Ridder) stresses the importance of manpower forecasts for policy making. 
ROA's view on the role of manpower forecasting is described by Dekker, De Grip and Heijke (1993, p. 47):

"The activities of ROA focus on increasing the transparency of the match between education and the labour market. A special effort is made to generate information on the labour market prospects of occupational groups and the graduates from various types of education. This information is primarily intended to assist young people in choosing an occupation or training course. The information can also play a role in answering policy questions as regards tuning training facilities to the needs of the labour market and how best to harness the potential of the population's qualifications to achieve economic growth."

This statement mentions both the information and the policy function. The emphasis is on the information function, however. Research done by Borghans (1993) stresses the importance of the information function. Borghans shows that the provision of good labour market forecasts improves both the labour market performance and the match between the educational system and the labour market. ROA's view is reflected in the fact that the manpower forecasts are embedded in a labour market information system for counselling purposes, called I-See! (see Heijke, 1993a).

It can be concluded that the two functions of manpower forecasting, the policy function and the information function, both occur nowadays. On the one hand, there are institutes which stress the policy function (for example: IER and IAB), while, on the other hand, institutes (for example BLS and ROA) consider manpower forecasts to be primarily a source of information for participants on the labour market. It should be noted, however, that emphasizing a function does not imply that the other function is ignored. The statements show that all four institutes mention both functions.

\subsection{Evaluation}

Irrespective of the (most important) function, using manpower forecasting implies a great confidence in the capability of manpower forecasts to improve the performance of the labour market. This observation raises several questions. In the first place, how are manpower forecasts supposed to improve the performance? In the second place, is it possible to underpin the confidence theoretically?

Nowadays there is a consensus with regard to the insignificance of manpower forecasting for planning purposes in Western economies. In a free market economy there is not much room for governmental planning. Nevertheless, using manpower forecasts as a policy instrument implies that the government is still considered to play an important role by intervening in the labour market. In other words, given the labour market failures, the government can take corrective measures to move towards (or even obtain) a (partial) labour market equilibrium and a Pareto optimal allocation. However, from a theoretical point of view, this view raises serious doubts. 
The economic theory dealing with the way in which the government should respond to market failures is the theory of second and third best (see $\mathrm{Ng}, 1983$ ). By means of this theory a theoretical argument for preferring the information function can be given.

It seems to be reasonable to assume that the more the conditions for a perfect market are satisfied, the higher social welfare will $\mathbf{b e}^{7}$. So, by restoring equilibrium on the labour market, a Pareto improvement seems to be achieved. However, the theory of second best states that restoring equilibrium on the labour market or a labour market segment does not necessarily imply a Pareto improvement anymore if other markets stay in disequilibrium. Possibly, social welfare even decreases. Perfect knowledge of the circumstances on the other markets is needed to find the optimal governmental policy measures to restore the Pareto optimal allocation on the market under consideration. There is no reason to assume that restoring equilibrium is the optimal measure. Deviating from the equilibrium may be better from a welfare point of view. It is impossible to have perfect knowledge with regard to the circumstances on all markets in the economy. however. Therefore, the impact of partial labour market measures on social welfare is not known. In other words, the theory of second best implies that government policies aiming to fill gaps between demand and supply on labour market segments predicted by manpower forecasting, may even worsen the problems. Therefore, unless there is perfect knowledge, there is no scope for government intervention at all.

The theory of second best states that perfect knowledge is needed to find the optimal measures. The theory of third best shows that, if there is imperfect knowledge, the available information can be used to find the expected optimal partial measure, given the distortions on other markets. However, still there is no reason to assume that the pursuit of filling the gaps between demand and supply completely is optimal. It can be shown, nevertheless, that applying the third best rule results into equalizing the gaps on all market segments (see $\mathrm{Ng}, 1983$ ).

This analysis shows that, from a welfare economic point of view, current forecasting practice overlooks two factors. In the first place, the government does not use the available information optimally. Governmental labour market policy does not take care of the performance of other markets or even other labour market segments. In other words, it is not effective to consider labour market problems in a partial context. In the second place, filling the gaps completely may not be the most optimal policy. Only if these two factors are taking into account, there seems to be some room for the policy function of manpower forecasting, although taking good measures from a welfare economic point of view may not be an easy task. However, the information generated by manpower forecasts can be used in a better way.

The better way consists in giving information to the agents on the labour market directly. Because making the market more transparent is also a policy measure to reduce distortions, the

7. Social welfare is the (weighted) sum of individual welfare (utility) levels. The relation between the individual welfare levels and social welfare is described by a social welfare function (see Varian, 1992). 
theories of second and third best can also be applied here. According to the theory of second best, making the labour market more transparent is no guarantee for a better performance from a welfare economic point of view. Simply removing one distortion (the lack of information) does not necessarily imply a higher social welfare. According to the theory of third best, making the market more transparent increases the amount of information available for individuals to take the optimal measures (that is, make the right decisions) to improve their own position on the labour market, which implies that it is also a good decision from a social welfare point of view. In that case, the labour market may come nearer to the 'first' best situation (that is, the equilibrium given the existing distortions).

At first sight, the theories of second and third best are unable to make a distinction between the policy function and the information function. According to the second best theory, manpower forecasting seems to be unable to contribute to Pareto improvements on the labour market. According to the third best theory, there seems to be room for both the policy function and the information function. However, inspired by Hayek (1945) it can be stated that individuals have an informational advantage on the government. On the one hand, the government has more scientific knowledge than the labour market agents. This implies that the government is more able to use the manpower forecasts adequately. On the other hand, however, labour market agents have an informational advantage. For example, they know their own preferences and capabilities. Hayek states that the impact of the governmental scientific advantage is smaller that the individual informational advantage. This implies that the agents on the labour market are expected to take better decisions. So, if the government passes on his knowledge in the form of manpower forecasts, the individuals have more information available to make the right decisions (for example, educational choices) according to the third best theory. In other words, the labour market may come nearer to the 'first' best situation if manpower forecasts are used as an informational instrument.

Another theoretical argument for using manpower forecasts to inform individuals is given by Borghans (1993). He shows that providing good manpower forecasts has a clear positive impact on social welfare, because individuals make better educational choices That is, students may increase their utility, because their information set becomes larger. Furthermore, the information may have a stabilizing effect on the labour market. Even if publishing manpower forecasts has a destabilizing effect on the labour market, social welfare will increase. The argument that providing labour market information has a destabilizing effect is often made. Kühlewind (1993b), for example, refers to the 'self-destroying prophecy' of occupational forecasts, which means that the market will over-react to the forecasts. Borghans shows, however, that this argument does not imply that providing manpower forecasting worsens the performance of the labour market. That is, social welfare increases. So, arguments like Kühlewind's can be refuted by means of welfare economic arguments.

Furthermore, the information function of manpower forecasting can be underpinned by means of empirical arguments. Labour market practice has shown that providing labour market information in general and manpower forecasts in particular improves the labour market 
performance. Labour market perspectives appear to play an important role in making educational choices. Providing labour market information appears to result in better individual choices $^{8}$.

Sometimes the statement seems to be made that the aim of making manpower forecasts is to predict the future as good as possible. This seems to be a very reasonable goal. A few remarks have to be made, however. Manpower forecasts often are presented as an answer to the question 'What would happen if no measures are taken?'. For example, the warning function of manpower forecasts, which Tessaring (1993) emphasizes, refers to this way of presentation. Given the fact that the policy makers or labour demand and supply are supposed to use the manpower forecasts to adjust their behaviour, however, the aim has to be that the forecasted gaps never occur. BLS, for example, evaluates his forecasts frequently. Rosenthal (1992) compares the predicted employment growth rates by occupation with the actual growth rates. This way of evaluating manpower forecasts only makes sense if the adjustmnets in the behaviour of labour market agents or policy adjustments are taken into account. The way in which BLS evaluates the forecasts seems to be in contradiction with the view of BLS on manpower forecasting, which implies an expected impact of publishing manpower forecasts on the agents' behaviour. This issue is a very important one. It seems to be recognized insufficiently, however. It implies that, unless the policy and behaviour adjustments are taken into account, the quality of manpower forecasts should be measured by looking at the labour market performance and the agents' behaviour instead of by comparing forecasts and outcomes.

It may be concluded that the most promising role of manpower forecasts is to provide information to make the labour market more transparent. This statement can be underpinned by both theoretical and empirical arguments. From a theoretical point of view, it can be shown that the performance of the labour market improves. From an empirical point of view, it is shown that students do react on these forecasts and make better individual choices. Today's practice, however, focuses to a considerable extent on the policy function of manpower forecasting. Furthermore, today's practice overlooks two important factors: (1) it is not effective to consider labour market problems in a partial context and (2) filling the gaps completely may not be the most optimal policy.

8. See, for some examples of studies with regard to the Dutch labour market, Heijke (1993a). 


\section{THE OUTPUT ${ }^{9}$}

\subsection{Introduction}

Before paying attention to the methodology, it should be clear what kind of forecasts are desired. This issue can be divided in two questions: (1) 'What kind of forecasts are made?' and (2) 'How are these forecasts presented?' This section discusses these questions. Furthermore, an evaluation of the current practice with regard to the output of manpower forecasting is made.

\subsection{The current practice}

The first question deals with the kind of forecasts which are made. Important aspects with regard to this question are: the way in which the labour market is segmented, the presentation of alternative scenarios and the time horizon of the forecasts.

With regard to the segmentation of the labour market two aspects can be distinguished: the dimension and the level of aggregation. ROA delivers the most extensive forecasts: both the occupational and the educational structure are presented. ROA distinguishes 93 occupational classes and 49 types of education.

IAB makes comparable forecasts, but on a much higher aggregation level. IAB forecasts employment by 34 'fields of activity' and 5 qualification levels. The term 'field of activity' is preferred to the term 'occupation' because, according to IAB, it is a much more objective term. Occupations differ with regard to industry, the worker's status origin and qualification profile, The 'fields of activity are defined in such way that they do not differ with regard to these aspects. Examples of 'fields of activity' are: executives, high-level R\&D, skilled work in production, skilled clerical work, cleaning and simple clerical work.

IER emphasizes the production of occupational forecasts. In their classification, 22 occupations are distinguished. However, separate forecasts for the higher types of education are made by government commission (Wilson et al., 1990).

A formal allocation of tasks between the Ministry of Education and BLS is due to the fact that BLS delivers occupational forecasts only. BLS uses a very low aggregation level; more than 200 occupations are distinguished.

Both IAB and BLS present forecasts based on different scenarios. IAB calls this 'the concept of alternative projections'. IER and ROA, on the other hand, present only one scenario. However, ROA uses an alternative to the use of scenarios: together with the occupational and educational

9. Section 3 and 4 are for a great deal based on: Bureau of Labor Statistics (1992b), Wilson (1993), Kühlewind (1993a) and Dekker, De Grip and Heijke (1993). 
forecasts two risk indicators are presented. These indicators measure the cyclical sensitivity of occupations and the possibilities of switching to another occupation or industry of types of education ${ }^{10}$.

Finally, as part of the first question, attention has to be paid to the time horizon of the forecasts. IAB uses the longest horizon: about thirty years. ROA's forecasts, on the other hand, have a rather short horizon: about five years. ROA mentions two arguments for the use of a relatively short horizon: changes on the labour market are more certain in the short run and short run forecasts are in alignment with the use for educational choices by students. IER (ten years) and BLS (between ten and fifteen years) have chosen a position between these extremes.

The second question deals with the way in which the forecasts are presented. Two aspects are relevant here: the degree in which the results are quantified and the emphasis on demand or on both demand and supply. With regard to the degree of quantification, there are two possibilities: presenting qualitative forecasts or presenting quantitative forecasts. On the one hand, IER present quantitative results. Detailed tables are given in which the forecasted structure of employment is shown (see, for example, IER, 1992). On the other hand, BLS and ROA prefer a qualitative presentation of the results. The quantitative forecasts are translated into qualitative categories. The Occupational Outlook Handbook of BLS is a famous example of this qualitative approach. Inspired by BLS, ROA translates the quantitative labour market prospects into five categories: very high, high, average, low and very low (see, for example ROA, 1992 and BLS, 1992b). It should be noted, however, that both ROA and BLS also present the quantitative prospects. Finally, IAB also uses both approaches. Apart from detailed quantitative forecasts (see, for example, Tessaring, 1991), also qualitative forecasts are published in the so-called ABC-Handbook. In contradiction to BLS's and ROA's work, the emphasis seems to be on quantitative forecasts, however.

With regard to the choice for presenting demand forecasts or both supply and demand forecastson a low aggregation level, IAB, IER, and BLS are demand-oriented. ROA, on the other hand, calculates gaps between demand and supply which are presented in a qualitative way.

In section 2 it became clear that, with regard to the function of manpower forecasting, a dichotomy can be made between ROA and BLS on the one hand and IER and IAB on the other. Partly, this dichotomy can also be made with regard to the output. On the one hand, ROA and BLS emphasize the presentation of qualitative forecasts with a relatively short time horizon on a low aggregation level, while, on the other hand, IER and IAB emphasize highly aggregated quantitative forecasts only with a relatively long time horizon. The dichotomy does not persist, however, with regard to the use of scenarios and, especially, the production of educational forecasts. BLS and IAB make use of scenarios, ROA and IER do not. BLS is the only institute that does not pay attention to educational forecasts, while ROA pays most attention to them.

10. For more details, see section 4 . 
Finally, IAB, IER and BLS are demand-oriented, while ROA calculates expected gaps between demand and supply.

\subsection{Evaluation}

In the previous subsection it became clear that the manpower forecasting practice emphasizes occupational forecasts (except ROA and, to a lesser extent, IAB). This is in alignment with the fact that current manpower forecasting practice is demand-oriented (except ROA again). It seems to be reasonable to assume that labour demand is formulated in terms of occupations initially. Workers are productive because they perform tasks and not because they have certain qualifications. A job consists of a set of tasks: an occupation. However, subsequently, a firm determines which types of education are needed to perform these tasks as good and as efficient as possible. In other words: first the labour demand is determined in terms of occupations. Later on, it is translated in terms of types of education. On the other hand, workers can be characterized by their types of education. So, labour supply can be determined in terms of types of education only.

Several conclusions can be drawn from the fact that demand can be determined in terms of both occupations and types of education, while supply can be determined in terms of types of education only. In the first place, the fact that the current manpower forecasting emphasizes demand and occupational forecasts is an inheritance from the manpower planning practice during the 1960s, which was completely demand-oriented. Secondly, describing both sides of the market necessarily implies that both occupational and educational forecasts have to be made. Finally, students make educational choices. So, in view of the preference for the information function, the emphasis should be on educational forecasts instead of occupational forecasts. At first sight, this implies that BLS's choice to make primarily occupational, demandoriented forecasts for information purposes does not seem to be a logical one. However, in the Occupational Outlook Handbook BLS provides also information with regard to the links between occupations on the one hand and types of education on the other. Furthermore, BLS has chosen a low aggregation level, which implies that there are a lot of unique one-to-one links between occupations and types of education. Therefore, direct educational forecasts are not needed anymore to give insight into the labour market perspectives of types of education.

In this context, attention has to be paid to IAB's reservedness with occupational forecasts. Two reasons are given: the 'self-destroying prophecy' of occupational forecasts, which has been discussed in section 2 and the subjectivity of occupational classifications. Therefore, they use a classification by 'field of activity'. However, a classification by 'field of activity' is in fact an occupational classification too. Therefore, IAB's objections seem to concern certain common occupational classifications, and not an occupational classification as such.

By discussing IAB's reservedness with regard to occupational forecasts, the second aspect has been broached, the aggregation level and, in connection with this, the occupational and educational classifications. There is a wide diversity among the institutes. Unfortunately, it may 
be concluded that the availability of data determines the aggregation level and the classification system instead of economic arguments. So, it may be useful to think of theoretically founded ways to classify occupations and types of educations (see, for example De Grip, Groot and Heijke, 1991). A possible way may consist in looking at substitution elasticities between occupations and between types of education by looking at production processes or estimating production functions. Another possibility may be to compute distances between occupations by investigating differences between tasks or types of education by investigating differences between skills. Finally. it should be noted that, in view of the preference for the information function, the educational classification should be as much as possible in alignment with the educational system of the country.

Another aspect mentioned above is the time horizon of the forecasts. Just like the aggregation level, manpower forecasting shows a rather diverse picture. In the 1960s, manpower forecasts had rather long time horizons, because required changes in the educational system were supposed to be large and time-consuming. Unfortunately, planning elements seem to persist. For example, both IAB and IER, making forecasts primarily for policy purposes, use a time horizon of respectively thirty and ten years. Possibly, the customer (that is, the government) determines the time horizon instead of, for example, the attempts to optimize the quality of the forecasts. Several arguments can be given for shortening the time horizon (that is, to choose a horizon of about five years). Firstly, it improves the quality of the forecasts. The longer the horizon, the more uncertain future developments are. In the second place, in the view of the preference of the information function, a medium-term horizon is preferred by the customers. Students want to be informed about their labour market position immediately after they finish their study, the investment plans of firms most of the time have a rather short time horizon and the educational policies have a rather short horizon too nowadays. In the third place, in view of the preference for the information function, it seems to be useful to provide information about career possibilities, for which long term forecasts are needed. However, providing such general information about career possibilities may be very difficult, because these possibilities are more related to individual capabilities than medium run perspectives by type of education. Finally, shortening the time horizon decreases the need to make use of scenarios. In the short run the benefits of distinguishing scenarios may be relatively low compared to the long run, simply because the difference between the scenarios may be relatively small.

This brings us to the next aspect: the usefulness of scenarios. IAB and BLS make use of scenarios, ROA and IER do not. Scenarios are used to overcome the uncertainty of future developments. However, only governmental policy makers are able to use the different scenarios effectively. They are able to calculate the probability that a particular scenario comes true. Possibly, the government is to some extent even able to influence the probability of a particular scenario. For students, on the other hand, it is more difficult to calculate the probabilities. Furthermore, they are unable to influence the outcomes. The best choice they can make, is to base their decisions on the outcomes of the central (or most likely) scenario. So, it can be concluded that, in view of the preference for the information function, providing 
scenarios is not very useful. There are better ways to overcome the uncertainty, for example providing risk-indicators, which is done by ROA.

The next aspect is the choice between a quantitative or qualitative presentation of the forecasts. If only quantitative forecasts are published, there are two possibilities. Providing point-estimates only, which is easy to interpret, or providing confidence intervals, which gives more information, but makes the interpretation more difficult. A way to solve this problem is using qualitative forecasts. Transforming quantitative forecasts into qualitative results combines two attractive features of point-estimates on the one hand and confidence intervals on the other. In the first place, it takes the uncertainty into account. For example, stating that the demand for carpenters will grow 'very fast' is less risky than stating that the demand for carpenters will increase by 15.4 percent. Secondly, the signals given by qualitative forecasts are clearer. So, they are easier to interpret than confidence intervals, which is very important in view of the preference for the information function. However, two remarks have to be made. In the first place, a lot of attention has to be paid to develop a good qualitative categorization system (see, for example, Wieling, De Grip and Willems, 1990). In the second place, in addition the quantitative results have to be presented also in order to meet the, as Lindley (1993) calls it, "more sophisticated users".

As mentioned above, current manpower practice is for a great deal demand-oriented. Supply forecasts are used to make the demand forecasts in alignment with the growth of the total labour force (see, for example, BLS, 1992b). This also implies that no attention is paid to the confrontation and interaction between (segmented) demand and supply. Especially in view of the preference for the information function, this is very unsatisfying. Students are not interested in the growth of labour demand. They are interested in their labour market perspectives; that is, their probability to get a job and the kind of job he or she is likely to get.

ROA tries to overcome this drawback by calculating gaps between demand and supply by type of education. A drawback of providing gaps between demand and supply is the danger that the gaps are interpreted as probabilities to get unemployed or to be unable to fulfil vacancies. Unemployment and vacancies, however, are not the only mismatch phenomenon. Other phenomena are: under- or overutilization of skills (as a result of downward displacement or upward substitution), student's wage expectations that do not come true, cobweb cycles and the need to work overtime. This implies that, from a theoretical point of view, two types of gaps can be calculated (see also Borghans and Heijke, 1993). The ex ante gap between demand and supply reflects the mismatch before interaction takes place. It is an indication for the probability to get the ideal job, that is a job in which the required qualifications are perfectly in alignment with the qualifications and of which characteristics are perfectly in alignment with the expectations of the student. This implies that this ex ante gap reflects the total amount of mismatch. The ex post gap between demand and supply reflects the directly visible mismatch after interaction has taken place. This interaction results into, for example, wage changes and downward displacement. If, after the interaction has taken place, there is still a gap, this gap reflects the number of unemployed lif supply exceeds demand) or the number of vacancies that 
cannot be fulfilled (if demand exceeds supply). Therefore, the ex post gap is an indicator for the probability to get employed.

ROA's gap approach has three important drawbacks. In the first place, ROA uses a specification of the demand function, in which supply is one of the explanatory variables ${ }^{11}$. This implies that the calculated gap can be interpreted as follows. After the supply forecasts by type of education are published, the demand side is allowed to react once to adjust its labour demand policy. After this first adjustment, the interaction process is finished. The gap that remains is delivered by ROA. In reality, the interaction process continues, however. Both supply and demand react on the mismatches that occur on their own submarket and on other submarkets. So, ROA's calculations yield neither the ex ante, nor the ex post gap. Therefore, from a student's point of view, it is very difficult to give an adequate interpretation of ROA's gap.

A second feature of ROA's approach leads to even more interpretation problems. The 'demand forecasts' are based on data reflecting market outcomes (that is, employment instead of requirements). This implies that the interpretation of the ex ante gap changes. The demand forecasts entails the outcomes of earlier interaction processes. Therefore, the interpretation of the ex ante gap seems to become even more difficult. The interpretation of the ex post gap remains the same, however. Ex post the way in which demand is forecasted is not relevant anymore (see Borghans and Heijke, 1993).

Thirdly, ROA's approach suggests that types of education or occupations can be compared with regard to the forecasted gaps. In other words, it is suggested that if the ex ante gap of type of education $A$ is larger that the gap of type of education $B$, the problems at submarket $A$ are more serious. However, two remarks have to be made here. In the first place, the size of the gap is no indicator for the size of the adjustments that have to take place. This implies that a gap in submarket $A$ is not comparable to a gap in submarket $B$. In the second place, a gap tells nothing about what kind of adjustments will take place. For example, suppose that wage decreases are considered to be a more serious problem than underutilization. If on submarket $B$ a small ex ante gap is 'closed' by a wage decrease, while on submarket A a large gap is 'closed' by means of downward displacement, the mismatch at submarket B could be considered to be more serious than the mismatch at submarket $A$, although the gap is smaller. So, gaps can not be compared; the gap size is a kind of ordinal measure.

So, in order to obtain a good economic interpretation of the gap, there are several possibilities. In the first place, trying to find ways to forecast demand separately. In that case, ex ante gaps could be calculated, reflecting the probability to get the ideal job. ROA's flexibility-indicator, could be added to show the opportunities to close gaps by means of under- or overutilization. However, it would be more attractive, from both an analytical and a practical point of view, to search for a good interaction model. In an interaction model, a lot of theoretical aspects can be

11. See, for more details, section 4 . 
used $^{12}$. From an analytical point of view, an interaction model has two advantages. In the first place, it would offer more insight into labour market processes. Secondly, there is no need anymore to make separate demand forecasts. The ex post gap is not related to the way in which the demand forecasts are made. From a practical point of view, the forecasts offer more useful information for students, because they offer a better insight in the students' labour market perspectives. It is possible then to give an overview of the probability to get a job, of the possibilities to get a job which is perfectly in alignment with the type of education and of the occupations in which the types of educations are used (horizontal educational flexibility), the way in which gaps are closed, for example the degree of under- and overutilization (vertical educational flexibility) and the degree in which gaps will persist reflected by the expected unemployment rate or the expected number of vacancies that can not be fulfilled. It should be mentioned here that ROA is working on an interaction model (see Borghans and Heijke, 1993).

It can be concluded that, in view of the preference for the information function, medium term, rather detailed, qualitative forecasts seem to be the most usable. The most important conclusion, however, is that current manpower forecasting practice is too much demandoriented, which implies that the emphasis is too much on occupational forecasts. Paying attention to both the demand and the supply side implies that both occupational and educational forecasts should be made. Furthermore, it implies that a way has to be found in which a confrontation between demand and supply can take place. There are two reasonable options. Firstly, calculating a gap before any interaction between demand and supply takes place. In that case, 'real' demand forecasts seem to be needed, however. Secondly, modelling the interaction and calculating the gap after the interaction has taken place. This second option is more attractive from both an analytical and a practical point of view.

In this section the output of manpower forecasting is discussed. In the next section, attention is paid to the way in which the output is produced: the methodology.

12. In section 4, more attention will be paid to the possibilities to improve the economic foundation of manpower forecasting models by means of an interaction model. 


\section{THE METHODOLOGY}

\subsection{Introduction}

In the first section, three questions are formulated. Two of them are answered in the previous sections. The third one deals the way in which the manpower forecasts are made. As mentioned in section 1, in the most extensive way making manpower forecasts nowadays consists of five stages:

1. forecasting employment by industry with the help of a multi-industry model;

2. using this forecast to forecast the occupational structure of labour demand by industry;

3. translating the occupational forecasts into forecasts of labour demand by education;

4. forecasting the educational structure of labour supply;

5. confronting the demand and supply forecasts.

In the next subsection attention is paid to the fourth stage: forecasting developments on the supply side of the labour market. Subsequently, the stages (2) and (3) are discussed: the methodology with regard to forecasting occupational and educational developments on the demand side of the labour market. As mentioned in the first section, stage (1) is left out. Finally, stage (5) has already been discussed in the previous section. Like the previous sections, this section is finished by an evaluation of the current methodology in manpower forecasting. Again, attention will be paid to the links with the other aspects: the role and the output.

\subsection{The supply side}

Forecasting the structure of the supply side of the labour market is a relatively underexposed element of manpower forecasting. As mentioned in the previous section, often only a forecast of the total labour force is made; no segmentation with regard to occupations and types of education is given. In principle, there are two methods to make supply forecasts. The stock accounting method uses forecasts of the participation rates by, for example, age and sex and the population growth by the corresponding subgroups. These two forecasts are multiplied to obtain a forecast of the labour force composition. The in- and outflow accounting method uses forecasts of in- and outflow rates by, for example, age and sex to obtain a forecast of the labour force composition. Both methods have a specific advantage. The stock accounting method yields relatively robust forecasts, while the in- and outflow accounting method yields relatively detailed forecasts (see Kühlewind, 1993a).

With regard to forecasting the supply, today's manpower forecasting practice shows a varying picture. ROA, which is the only institute making educational supply forecasts, uses the in- and outflow accounting method. It uses forecasts of the Dutch Ministry of Education and Science with regard to the inflow of school leavers. The outflow is incorporated in the replacement demand model (see below). BLS relies heavily on the stock accounting method, although it recently started to use the in- and outflow method also (see BLS, 1992b). The labour force composition by age, sex and race is computed by multiplying forecasted participation rates and population projections. IER applies a combination of both methods. On a highly aggregated 
level, the in- and outflow accounting method is used to obtain a forecast of the total labour force. Subsequently, participation rate forecasts are used to obtain the labour force composition. Finally, IAB decides on a case by case basis which method is applied.

\subsection{The demand side}

Compared to the supply side, much more attention has been paid to making forecasts with regard to the demand side. In this subsection the methodology used by the four institutes to make forecasts with regard to the occupational and educational structure of labour demand is described.

BLS has developed a methodology which still bears much resemblance with the well-known manpower requirements approach. The forecast of employment by industry, which is obtained by combining forecasts of industrial output and industrial productivity projections (see BLS, 1992b), is multiplied by the forecasted staffing patterns, that is the occupational structure within an industry. Staffing pattern forecasts are obtained by extrapolating trends from the past. Furthermore, a team of experts is consulted to judge the forecasts and to add assumptions with regard to future developments in particular industries and occupations ${ }^{13}$. In an iterative process the quantitative information obtained by the extrapolations and the qualitative information obtained by the consulting experts are brought in alignment. The result is a forecast of employment growth by occupation. Replacement demand forecasts are added. The replacement demand reflects the available job openings as a result of outflow of workers due to retirement, occupational mobility etc.. Adding up employment growth and replacement demand yields the total number of job openings. In this way, the forecasts are fit for students, who are interested in their labour market perspectives, that is opportunities to find a job (see BLS, 1992a).

IAB's demand forecasting method is also based on the manpower requirements approach. Starting point is the forecast of the industrial employment again, which is obtained by dividing the forecasted industrial production by forecasts of the labour productivity. Subsequently employment by 'field of activity' is forecasted by extrapolating past trends. Eventually, studies concerning the impact of technologies and socio-economic changes are used to adjust trends for these developments. Subsequently, employment by level of qualification is also forecasted by means of trend extrapolation.

IER obtains forecasts of the industrial employment out of a macroeconomic labour demand equation by means of a multi-industry macroeconomic model. Subsequently, trend extrapolation techniques are used to forecast the occupational structure by industry ${ }^{14}$. Combining these occupational coefficients with industrial employment yields industrial employment by

13. See, for an example of these assumptions, part III of BLS (1992b).

14. It should be noted here that IER is currently working on an explanatory model. 
occupation. As mentioned above, apart from the occupational forecasts, IER has developed a model for higher types of education. Based on links between the educational and occupational structure in the past, the future educational structure is obtained again by trend extrapolation.

The base structure of ROA's demand forecasting methodology is similar to the methodology of the other institutes. Starting point are the forecasts of the industrial employment, from which successively the future occupational and educational structures are obtained. Like BLS, a distinction is made between employment growth (which is called expansion demand by ROA) and replacement demand ${ }^{15}$. ROA's approach is different from others in several aspects.

In the first place, ROA uses explanatory models instead of trend extrapolations to forecast the occupational and the educational structure (see Dekker, De Grip and Heijke, 1993). Firstly, the demand by 54 occupational segments is forecasted. The explanatory equation consists of two elements: an industry and occupation specific intercept variable and a technology variable, measured by a capital to labour ratio. This variable is specified as the ratio between total capital investment during the last ten years on the one hand and a five-year moving average of employment on the other hand. Subsequently, this forecast is translated into a forecast by occupational class. ROA distinguishes 93 occupational classes. The translation is carried out by means of trend extrapolation. The next step is making a forecast of the demand by educational discipline, which is also done by trend extrapolation. In the final step demand by educational level within the disciplines is forecasted. Two explanatory variables are used here: a lagged endogenous variable and a supply variable, which is already mentioned in section $3^{16}$.

In the second place, ROA calculates several risk indicators. The first indicator reflects the cyclical sensitivity of occupations. It is calculated in two stages. In the first stage the annual absolute divergences of industrial employment from a trend value are determined and added. This called the fluctuation index. In the second stage a fluctuation index by occupation is derived by adding the industrial fluctuation indices weight by the industry share in the occupation class. Three other indicator are already mentioned in section 3 . They reflect respectively the possibility of industrial mobility of occupations and types of education and the possibility of occupational mobility of a type of education. They are calculated by means of a dispersion index: the Gini-Hirschman coefficient. These indexes show the degree of dispersion of an occupation over the industries and of a type of education over the industries and the occupations. These two indicators reflect the risk of making a particular choice. The higher the cyclical sensitivity index and the lower the dispersion indexes, the higher the risk.

This brief survey shows that the following picture of the current demand forecasting methodology can be drawn. Given the industrial employment, IAB, IER and BLS make

15. See, for the methodology for making replacement demand forecasts, Willems and De Grip (1993).

16. It should be noted here that ROA has been developing new models and techniques to make demand forecasts. These models and techniques are used to make the most recent forecasts which will be published in ROA (1993). 
occupational and educational forecasts by means of trend extrapolation. Eventually, these forecasts are adjusted for qualitative judgements. ROA has added explanatory variables: a technology variable (occupational forecasts) and a supply variable (educational forecasts). Dekker, De Grip and Heijke (1993) show that ROA tried to incorporate other explanatory variables into the model. Unfortunately, estimation by means of the more extended models gave unsatisfying results. Although the limitations of the currently used methodology are recognized, resignation seems to have the upper hand. Data limitations are considered to be the most important reason for this stagnation. Furthermore, an attractive feature of trend extrapolation is its simplicity. Except the interaction model of ROA mentioned in section 3, no methodological improvements seems to be in store in the short run. More attention is paid nowadays to improving the econometric methods used to make the forecasts (see, for example, Peeters (1990) and Wilson (1993) and new methods to forecast industrial employment (see, for example, Kühlewind, 1993a).

\subsection{Evaluation}

In the previous subsections a brief review is given on the methodology used to make supply and demand forecasts. With regard to the supply forecasts it is shown that here are two methods: the stock accounting method and the in- and outflow accounting method. The in- and outflow accounting method is preferable to the stock accounting method from a theoretical point of view. The in- and outflow accounting method offers more opportunities to explore the causes of changes in the size and composition of the labour force. Drawbacks of the in- and outflow accounting method are the complexity and the fact that more data are required, however. It should be repeated here that, except ROA's forecasts, no forecasts of the occupational and educational structure of the labour force are made. In section 3 it is stated that these forecasts are very useful, in particular in view of the preference for the information function. It seems to be reasonable to assume that, in the short run, the occupational and educational structure of the labour force fluctuates more than, for example, the composition by age or by sex. Therefore, a more advanced and detailed supply model is required to forecast these fluctuations. The in- and outflow accounting method seems to be more appropriate than the stock accounting method to cope with the degree of detail that is required.

With regard to the demand forecasts it is already emphasized that the methodology heavily relies on trend extrapolation for reasons of simplicity and data limitations. Particulary from a theoretical point of view, this conclusion is rather disappointing. Trend extrapolation has several drawbacks. In the first place, trend extrapolations do not give insight into the factors causing the changes in the occupational and educational structure. This seems to be a theoretical drawback only. It has also practical importance, however. If trend extrapolation is used, there is little scope for using evaluations to learn from mistakes in the past. There is little scope for using forecasting experience to polish the methodology theoretically. Attempts are made to overcome this lack of theoretical foundation by incorporating qualitative information into the forecasts. These attempts are not very attractive, because they are either ad hoc (for example, IAB) or very time-consuming (for example, BLS). Furthermore, no clear concept how to combine 
quantitative and qualitative information is available ${ }^{17}$. Econometric theory states that, if an economic foundation of systematic processes can be found, using the economic theory to construct an econometric model yields better results ${ }^{18}$. In the second place, the past data are used in a wrong way. Past data do not reflect labour demand but market outcomes after interactions between demand and supply have occurred. This feature of past data supports the plea for more emphasis on the modelling of the interaction between demand and supply in the previous section.

ROA's analysis shows that using extended explanatory demand models does not seem to yield very satisfying results either. So, this approach does not seem to be an attractive alternative for trend extrapolation. More important may be the data limitations with regard to demand forecasting. Historical data reflect labour market outcomes instead of developments in labour demand. Therefore, also from this point of view, it seems to be recommendable to shift the attention to modelling the interaction process between supply and demand. There are several possibilities for further research. In the first place, the modelling of horizontal substitution processes. In this context, attention has to be paid to substitution processes on the demand side (production technologies) and the occupational flexibility of educated people. In the second place, the modelling of vertical substitution processes. In this context, attention has to be paid to the modelling of downward displacement and upward substitution. Thirdly, ways to incorporate unemployment into the model. Finally, a mathematical way to model the interaction between demand and supply.

17. This problem is also discussed by Lindley (1993).

18. See, for example, Judge et al. (1982), pp. 699-701. 


\section{CONCLUSIONS: A VIEW ON THE FUTURE OF MANPOWER FORECASTING}

\subsection{The current state of the art}

To summarize the current state of the art, today's practice is reflected in the table below. In this table, the aspects discussed in this paper return. In the first place the function of making manpower forecasts. Secondly, the time horizon in years. Thirdly, the dimension of the forecasts, in particular the provision of education forecasts. In the fourth place the aggregation level, which is reflected by the number of occupations and, possibly, educations. In the fifth place, the use of scenarios. Sixthly, the output and, finally, the methodology with regard to supply and demand.

Table 1. The current state of the art

\begin{tabular}{|c|c|c|c|c|}
\hline & BLS & IAB & IER & ROA \\
\hline \multicolumn{5}{|l|}{ emphasis on information } \\
\hline function & yes & no & no & yes \\
\hline \multicolumn{5}{|l|}{ dimension } \\
\hline occupational forecasts & yes & yes & yes & yes \\
\hline educational forecasts & no & yes & no & yes \\
\hline \multicolumn{5}{|l|}{ aggregation level } \\
\hline occupations & $>200$ & 34 & 22 & 93 \\
\hline types of education & & 5 & & 54 \\
\hline scenarios & yes & yes & no & no \\
\hline \multicolumn{5}{|l|}{ output } \\
\hline quantitative & yes & yes & yes & yes \\
\hline $\begin{array}{l}\text { qualitative } \\
\text { confrontation }\end{array}$ & yes & yes & no & yes \\
\hline demand and supply & no & no & no & yes \\
\hline \multicolumn{5}{|l|}{$\begin{array}{l}\text { demand and suppiy } \\
\text { methodology supply }\end{array}$} \\
\hline stock & yes & yes & no & no \\
\hline in-outflow & yes & yes & yes & yes \\
\hline \multicolumn{5}{|l|}{$\begin{array}{l}\text { methodology demand } \\
\text { (adjusted) trend }\end{array}$} \\
\hline extrapolation & yes & yes & yes & yes \\
\hline $\begin{array}{l}\text { explanatory models } \\
\text { replacement demand }\end{array}$ & no & no & no & yes \\
\hline forecasts & yes & no & no & yes \\
\hline additional information & & & & \\
\hline by means of indicators & no & no & no & yes \\
\hline
\end{tabular}

\subsection{A view on the future of manpower forecasting}

Although some people are saying that manpower forecasting should be banned (see, for example, Psacharopoulos, 1991), this paper shows that manpower forecasting still has a promising future. However, this paper shows also that a change in the way of thinking about manpower forecasting seems to be recommendable. Both from a theoretical and a practical 
point of view, the information function seems to be more attractive than the 'good-old' policy function. This paper shows that emphasizing the information function should have several important implications for manpower forecasting practice:

1. a shortening of the time horizon to the medium term (about five years);

2. a switch from demand-oriented to student-oriented forecasting. This implies that both demand and supply forecasts are required;

3. more emphasis on educational forecasts;

4. an educational classification that is in alignment with the national educational system;

5. the avoidance of the use of scenarios;

6. the publication of confrontations between demand and supply forecasts;

7. the publication of relevant information for students;

8. the publication of the forecasting results in a comprehensible way.

However, this is not the end of the story. Lindley (1993) mentions four ways to spend available resources: (1) data preparation, (2) economic research, (3) operational forecasting and (4) dissemination. Irrespective of the chosen role, it may be useful to adjust the current distribution of resources over these activities. It may be worthwhile to shift the attention from data preparation and operational forecasting somewhat towards economic research and dissemination. The dissemination aspect has been mentioned before. The forecasting results have to published in a for students functional way. This implies that more research has to be done to determine in which aspects students are interested. The proposed shift from data preparation and, in particular, operational forecasting towards economic research needs a further explanation.

Given the data limitations, the current manpower forecasting practice seems to be mainly directed to using the available data in a, from an econometric point of view, efficient way. A lot of attention is paid to improving the econometric methods, that is to operational forecasting. Unfortunately, this is at the expense of economic research. The term 'economic model' is mainly used nowadays to stress that total industrial labour demand is forecasted by means of a complete macroeconomic model. The economic models used to make occupational and educational forecasts have hardly been refined during the last ten years, however. These models still suffer from a serious lack in economic foundation. So, it may be useful to shift the attention to using the data in an efficient way from an economic point of view. In other words, it may be useful to shift the attention from data preparation and operational forecasting to economic research.

An economic foundation could be given for three aspects of the labour market: (1) developments on the supply side, (2) developments on the demand side and (3) the interaction between demand and supply. These aspects have already been discussed before. It is useful, however, to repeat the most important conclusions here. With regard to the developments on the supply side, educational forecasts are needed. There seems to be little scope, however, for further economic foundation. With regard to the developments on the demand side, it may be difficult to obtain good data to forecast 'real' developments. Therefore, the most promising 
aspect seems to be the interaction between demand and supply. Modelling the interaction, however, implies also modelling the behaviour of the demand and the supply side. For example, modelling the occupational flexibility of labour supply and the educational flexibility of labour demand may be very useful. 


\section{REFERENCES}

Blaug, M. (1967), 'Approaches to Educational Planning', The Economic Journal, vol. 76, june, pp. 262-287.

Borghans, L. (1993), Educational Choice and Labour Market Information, Thesis, Maastricht.

Borghans, L. and Heijke, H. (1993), Forecasting the Educational Structure of Occupations: $A$ Manpower Requirements Approach with Substitution, ROA-RM-1993/2E, Maastricht.

Bureau of Labor Statistics, Occupational Outlook Handbook, Government Printing Office, Washington D.C., various editions.

Bureau of Labor Statistics (1992a), Occupational Projections and Training Data; Statistical and Research Supplement of the 1992-93 Occupational Outlook Handbook, Bulletin 2401, Government Printing Office, Washington D.C..

Bureau of Labor Statistics (1992b), Outlook 1990-2005, Bulletin 2402, Government Printing Office, Washington D.C..

Centraal Planbureau (1987), De Arbeidsmarkt naar Opleidingscategorie 1975-2000, CPBwerkdocument nr. 17, Den Haag.

Dekker, R., De Grip, A and Heijke, H. (1993), 'Indicating the Future Labour Market Prospects of Occupational Groups and Types of Education in the Netherlands', in: Heijke, H. (ed), Forecasting the Labour Market by Occupation and Education, Kluwer Academic Publishers, Boston, Dordrecht, London (forthcoming).

De Grip, A., Groot, L.F.M. and Heijke, J.A.M. (1991), 'Defining Occupational Groupings by Educational Structure', Environment and Planning, vol. 23, pp. 59-85.

Hayek, F.A. (1945), 'The Use of Knowledge in Society', American Economic Review, vol. 35, september, pp. 519-530.

Heijke, J.A.M. (1993a), 'Achtergronden en Opzet van het Informatiesysteem OnderwijsArbeidsmarkt van het ROA', in: Spijkerman, R.M.H., Vincken, A.J.R. and Weekenborg, M.J.M. (eds), Handboek Studie- en Beroepskeuzebegeleiding, Samson H.D Tjeenk Willink, Alphen aan de Rijn.

Heijke, H. (1993b), 'ROA's Activities and Plans Relating to the Information System on Education and the Labour Market' in: Heijke, H. (ed), Forecasting the Labour Market by Occupation and Education, Kluwer Academic Publishers, Boston, Dordrecht, London (forthcoming). 
Hughes, G. (1993), Projecting the Occupational Structure of Employment in OECD Countries, OECD Labour Market and Social Policy Occasional Papers nr. 10, OECD, Paris.

Institut für Arbeitsmarkt und Berufsforschung, $A B C$-Handbook, IAB, Nürnberg, various editions.

Insitute for Employment Research (1992), Review of the Economy and Employment: Occupational Assessment, University of Warwick, Coventry.

Judge, G.G., Carter Hill, R., Griffiths, W.E., Lütkepohl, H. and Lee, T. (1982), Introduction to the Theory and Practice of Econometrics, John Wiley \& Sons, New York.

Kühlewind, G. (1993a), Long-Term Labour Market Projections - Methods and Results for the Federal Republic of Germany, IAB topics, no. 3, IAB, Nürnberg.

Kühlewind, G. (1993b), 'IAB's Medium and Long Term Labour Market Projections; Selected Aspects', in: Heijke H. (ed), Forecasting the Labour Market by Occupation and Education, Kluwer Academic Publishers, Boston, Dordrecht, London (forthcoming).

Lindley, R.M. (1993), 'A Perspective on IER Forecasting Activities and Future Developments', in: Heijke, H. (ed), Forecasting the Labour Market by Occupation and Education, Kluwer Academic Publishers, Boston, Dordrecht, London (forthcoming).

Nederlands Economisch Instituut (1983), Prognose van de Werkgelegenheid naar Sector en Beroep 1983-1988, Rotterdam.

Nederlands Economisch Instituut (1986), Een verkenning van de Arbeidsmarkt naar Beroep en Opleiding tot 1990, OSA-werdocument $\mathrm{nr} .17$, Zoetermeer.

$\mathrm{Ng}$, Y. (1983), Welfare Economics, Macmillan, London.

Parnes, H.S. (1962), Forecasting Educational Needs for Economic and Social Development, OECD, Paris.

Peeters, H.M.M. (1990), An Explanation of the Occupational and Educational Structure of Employment by means of Multinomial Logit, ROA-W-1990/4E, Maastricht.

Psacharopoulos, G. (1987), 'The Manpower Requirements Approach', in: Economics of Education: Research and Studies, Pergamon Press, Oxford.

Psacharopoulos, G. (1991), 'From Manpower Planning to Labour Market Analysis', International Labour Review, vol. 130, no. 4, pp. 459-470. 
Researchcentrum voor Onderwijs en Arbeidsmarkt (1992), De Arbeidsmarkt naar Opleiding en Beroep tot 1994, ROA-R-1992/1, Maastricht.

Researchcentrum voor Onderwijs en Arbeidsmarkt (1993), De Arbeidsmarkt naar Opleiding en Beroep tot 1998, ROA-R-1993/10, Maastricht.

Rosenthal, N.H. (1992), 'Evaluating the 1990 Projections of Occupational Employment', Monthly Labor Review, vol. 115, August, pp. 32-48.

Tessaring, M. (1991), 'Tendenzen des Qualifikationsbedarfs in der Bundesrepublik Deutschland bis zum Jahre 2010', in: Mitteilungen aus der Arbeitsmarkt- und Berufsforschung, vol. 24, nr. 1 , pp. 45-62.

Tessaring, M. (1993), 'Manpower Requirements by Levels of Qualification in the Federal Republic of Germany until 2010', in: Heijke, H. (ed), Forecasting the Labour Market by Occupation and Education, Kluwer Academic Publishers, Boston, Dordrecht, London (forthcoming).

Van Eijs, P. (1993), The Manpower Requirements Approach: Background and Methodology, ROA-RM-1993/3E, Maastricht.

Varian, H.R. (1992), Microeconomic Analysis, W.W. Norton \& Company, New York, London, third edition.

Voorlopige Nationale Havenraad (1982), Kwalitatieve Aspecten van de Arbeidsmarktontwikkeling in Zeehavengebieden: eindrapport, Den Haag.

Wieling, M.H., De Grip, A. and Willems, E.J.T.A. (1990), Een Systematische Kwalitatieve Typering van Arbeidsmarktinformatie, ROA-W-1990/8, Maastricht.

Willems, E.J.T.A and De Grip, A. (1993), Forecasting Replacement Demand by Occupation and Education, International Journal of Forecasting, vol. 9, pp. 173-185.

Wilson, R.A. (1993), 'Modelling and Forecasting the Structure of Employment in the United Kingdom', in: Heijke, H. (ed), Forecasting the Labour Market by Occupation and Education, Kluwer Academic Publishers, Boston, Dordrecht, London (forthcoming).

Wilson, R.A., Bosworth, D.L. and Taylor, P.C. (1990), Projecting the Labour for the Highly Qualified, IER, University of Warwick, Coventry. 